\title{
Effect of Tillage and Nutrient Management Practices to Pole Bean (Phaseolus vulgaris L.) on Nutrient Uptake, Soil Fertility Status and Microbial Population
}

\author{
Nilesh Shiragavi $^{1}$, D. Krishnamurthy ${ }^{1 *}$, Y.M. Ramesha ${ }^{2}$, H.S. Latha ${ }^{1}$ and \\ K. Nrayanarao ${ }^{3}$ \\ ${ }^{1}$ Department of Agronomy, AICRP on Sorghum, ARS, Hagari, Karnataka, India \\ ${ }^{2}$ Department of Agronomy, ARS, Dhadesugur, Karnataka, India \\ ${ }^{3}$ Department of Soil Science, University of Agricultural Sciences, Raichur-584 104 \\ (Karnataka), India \\ *Corresponding author
}

\begin{tabular}{|c|}
\hline Keywords \\
\hline $\begin{array}{l}\text { Polebean, Tillage, } \\
\text { Nutrient uptake and } \\
\text { microbial } \\
\text { population }\end{array}$ \\
\hline Article Info \\
\hline $\begin{array}{l}\text { Accepted: } \\
16 \text { August } 2018 \\
\text { Available Online: } \\
\text { 10 September } 2018\end{array}$ \\
\hline
\end{tabular}

\section{A B S T R A C T}

A Field experiment was conducted at Agricultural Research Station, Dhadesugur on deep black soil during rabi-2017. The experiment was replicated thrice in split plot design. There were ten treatment combinations consisted of tillage practices in main plot and nutrient management practices in sub plot. Among the main plot treatments, conventional tillage recorded significantly higher uptake of nitrogen, phosphorus and potassium (40.11, 17.15 and $38.38 \mathrm{~kg} \mathrm{ha}^{-1}$, respectively), and bacterial, fungal and actinomycetes (65.5 CFU $\times 10^{-6} \mathrm{~g}^{-1}, 21.9 \mathrm{CFU} \times 10^{-4} \mathrm{~g}^{-1}$ and $37.5 \mathrm{CFU} \times 10^{-3} \mathrm{~g}^{-1}$, respectively) population over reduced tillage. Among sub plot treatments, application of recommended dose of fertilizer with FYM recorded significantly higher uptake of nitrogen, phosphorus and potassium (47.31, 22.14 and $44.96 \mathrm{~kg} \mathrm{ha}^{-1}$, respectively) and bacterial, fungal and actinomycetes (82.7 CFU $\times 10^{-6} \mathrm{~g}^{-1}, 28.3 \mathrm{CFU} \times 10^{-4} \mathrm{~g}^{-1}$ and $47.5 \mathrm{CFU} \times 10^{-3} \mathrm{~g}^{-1}$, respectively) population over all other treatments. Interaction of main and sub plot treatments, significantly higher uptake of nitrogen, phosphorus and potassium $\left(50.38,22.64\right.$ and $46.96 \mathrm{~kg} \mathrm{ha}^{-1}$, respectively) and bacterial, fungal and actinomycetes (83 CFU $\times 10^{-6} \mathrm{~g}^{-1}, 28.7 \mathrm{CFU} \times 10^{-4} \mathrm{~g}^{-1}$ and 49.0 $\mathrm{CFU} \times 10^{-3} \mathrm{~g}^{-1}$, respectively) population were observed in conventional tillage along with recommended dose of fertilizer and FYM compared to all other treatments. Whereas, significantly higher available of nitrogen, phosphorous and potassium content in soil $\left(155.3,54.3\right.$ and $290.6 \mathrm{~kg} \mathrm{ha}^{-1}$, respectively) was observed in reduced tillage with organic nutrient management practices. Conventional tillage with unfertilized control recorded significantly lower available of nitrogen, phosphorous and potassium content in soil (115.1, 46.5 and $271.5 \mathrm{~kg} \mathrm{ha}^{-1}$, respectively).

\section{Introduction}

Polebean (Phaseolus vulgaris L.) is an important vegetable crop belongs to the family
Fabaceae. It is also known as kidney bean, snap bean, French bean and wax bean. It is cultivated for the vegetable, shelled green beans and dry beans (Rajmah). Being a 
leguminous crop French bean is rich in protein and minerals. Production of Polebean can be increased either by increasing the area of cultivation or by improving the cultivation practices. It is not possible to increase the area of cultivation in the present situation and on the other hand productivity in India is less as compared to world average.

Among several factors responsible for lower productivity, improper nutrient management and tillage practices are the major factor. Tillage is a practice, which changes the physical properties of soil and enables the plants to attain their full potential.

Tillage techniques are used in order to provide a good seedbed, root development, weed control, and manage crop residues, leveling the surface for uniform irrigation and incorporation of fertilizers (Cabeda, 1984) and combined application of organic manures and inorganic fertilizers that improves physical and chemical conditions of soil and soil productivity but the use of inorganic fertilizer alone for a long period deteriorates the physical properties, organic matter status and reduces crop yield. Therefore, considering the above facts, the present study was planned and executed accordingly.

\section{Materials and Methods}

The field experiment was carried out at Agricultural Research Station, Dhadesugur, during rabi-2017 to study "effect of tillage and nutrient management practices to pole bean (Phaseolus vulgaris L.) on nutrient uptake, soil fertility status and microbial population".

The experiment was replicated thrice in split plot Design. There were ten treatment combinations consisted of tillage practices in main plot (conventional and reduced tillage) and nutrient management practices in sub plot
(Recommended dose of fertilizer (RDF + FYM), recommended dose of inorganic fertilizer (RDF), integrated nutrient management (INM), organic nutrient management (ONM), Control). The composite soil samples from 0 to $15 \mathrm{~cm}$ depth were collected before planting and at harvest. Soils were air dried in shade, powdered and passed through $2 \mathrm{~mm}$ sieve and analysed for $\mathrm{pH}, \mathrm{EC}$, OC, available $\mathrm{N}, \mathrm{P}_{2} \mathrm{O}_{5}$ and $\mathrm{K}_{2} \mathrm{O}_{5}$ by following the methods described by Jackson (1973) and microbial population as outlined by (Pramer and Schmidt, 1964). The soil was deep black soils with $\mathrm{pH}$ 8.23. The available $\mathrm{N}, \mathrm{P}_{2} \mathrm{O}_{5}$ and $\mathrm{K}_{2} \mathrm{O}$ contents were 165(low), 55.2 (high) and 300.4 (high) $\mathrm{kg} \mathrm{ha}^{-1}$, respectively. The gross plot size was $9.6 \mathrm{~m} \mathrm{x} 3.6 \mathrm{~m}$ and net plot size was $7.2 \mathrm{~m} \mathrm{x} 3.0$ and spacing of $120 \mathrm{~cm}$ x 30 $\mathrm{cm}$ and the recommended package of practices were adopted for crop production. The crop was harvested at its physiological maturity. The data was statistically analysed as per the procedure given by Panse and Sukhatme (1967).

\section{Results and Discussion}

\section{Nutrient uptake}

Among the tillage practices, conventional tillage recorded significantly higher uptake of nitrogen, phosphorus and potassium (40.11, 17.15 and $38.38 \mathrm{~kg} \mathrm{ha}^{-1}$, respectively) over reduced tillage $\left(37.27,16.19\right.$ and $35.16 \mathrm{~kg} \mathrm{ha}^{-1}$, respectively).

Among nutrient management practices, application of recommended dose of fertilizer with FYM recorded significantly higher uptake of nitrogen, phosphorus and potassium (47.31, 22.14 and $44.96 \mathrm{~kg} \mathrm{ha}^{-1}$, respectively) over all other treatments. Unfertilized control recorded significantly lower uptake of nitrogen, phosphorus and potassium (25.33, 9.57 and $23.48 \mathrm{~kg} \mathrm{ha}{ }^{-1}$, respectively). Interaction of main and sub plot treatments on 
uptake of nitrogen, phosphorus and potassium at harvest of polebean differed significantly. Significantly higher uptake of nitrogen, phosphorus and potassium (50.38, 22.64 and $46.96 \mathrm{~kg} \mathrm{ha}^{-1}$ respectively) were observed in conventional tillage along with recommended dose of fertilizer and FYM compared to all other treatments (Table 1). Reduced tillage with unfertilized control recorded significantly lower uptake of nitrogen, phosphorus and potassium $\left(24.24,9.23\right.$ and $21.87 \mathrm{~kg} \mathrm{ha}^{-1}$ respectively) followed by conventional tillage with unfertilized control (26.45, 9.91 and $25.13 \mathrm{~kg} \mathrm{ha}^{-1}$ respectively).

Nitrogen being a structural component of proteins at either as storage protein or proteins involved in various biological functions. Increase in uptake due of $\mathrm{N}$ was also attributed to increase in dry matter production and content Jakhar et al., (2005), Veeresh (2003). Increased phosphorus uptake mainly due to conversion of fixed phosphorus into readily available form by organic acids released during decomposition of composts Muthuramalingam et al., (2002). Adequate supply of water throughout crop growth due to favourable condition of soil under conventional tillage and this in turn improved potassium content and uptake as it is mainly absorbed through diffusion Prasad et al., (1998) and Veeresh (2003).

\section{Soil fertility status}

Significantly higher available of nitrogen, phosphorous and potassium content in soil (155.3, 54.3 and $290.6 \mathrm{~kg} \mathrm{ha}^{-1}$, respectively) was observed in reduced tillage with organic nutrient management practices. Conventional tillage with unfertilized control recorded significantly lower available of nitrogen, phosphorous and potassium content in soil (115.1, 46.5 and $271.5 \mathrm{~kg} \mathrm{ha}^{-1}$, respectively) followed by reduced tillage with unfertilized control (117.2, 47.5 and $273.7 \mathrm{~kg} \mathrm{ha}^{-1}$, respectively). This may be due to lower uptake of nutrients and lower green pod yield and stalk yield, which leads to lower utilization of nutrients present in soil and makes more availability to the next subsequent crop. The soil application with recommended chemical fertilizer and FYM may increases the utilization of nutrients mainly due to its beneficial effect in mobilizing the native nutrients to increases their uptake and ultimately leads to lower availability in soil after the harvest. These results are conformity with Dhawan et al., (1992) and Prasad (1994).

Further, available nitrogen content in soil increased with the application of organics alone or in combination with fertilizers under different tillage practices. This may be attributed to addition of nitrogen to soil through organics and its slow release pattern throughout the growth period, which might have minimized nitrogen loss. These results are in line with Reddy and Reddy (1998) and Abdulkadir (2000). Maximum available phosphorus content in soil with the application of organic nutrient management practices under reduced and conventional tillage practices may be attributed to more phosphorus added to soil. In addition to this, organic acids and carbon dioxide released during decomposition might have acted on native insoluble iron and aluminium phosphates resulting in release of insoluble phosphorus or might have chelated active $\mathrm{Fe}^{3+}$ and $\mathrm{A}^{3+}$ reducing fixation or formation of insoluble iron and aluminium phosphates (Sharma and Saxena, 1985). Potassium content of soil increased with the application of with the application of organic nutrient management practices under reduced and conventional tillage practices (Table 2) which may be due to addition of more potassium to the soil through composts alone or in combination with chemical fertilizers. Reddy and Reddy (1998) also obtained similar results. 
Table.1 Uptake of Nitrogen, phosphorous and potassium $\left(\mathrm{kg} \mathrm{ha}^{-1}\right)$, as influenced by tillage and nutrient Management practices in pole bean

\begin{tabular}{|c|c|c|c|c|c|c|c|c|c|}
\hline \multirow{3}{*}{$\begin{array}{c}\text { Nutrient } \\
\text { management } \\
\text { practices (S) }\end{array}$} & \multicolumn{9}{|c|}{ Tillage practices (M) } \\
\hline & \multicolumn{3}{|c|}{ Nitrogen } & \multicolumn{3}{|c|}{ Phosphorous } & \multicolumn{3}{|c|}{ Potassium } \\
\hline & \multicolumn{2}{|r|}{$\mathbf{M}_{2}$} & Mean & $\mathbf{M}_{1}$ & $\mathbf{M}_{2}$ & Mean & $\mathbf{M}_{1}$ & $\mathbf{M}_{2}$ & Mean \\
\hline $\mathbf{S}_{1}$ & 44.27 & 50.38 & 47.31 & 21.65 & 22.64 & 22.14 & 43.24 & 46.69 & 44.96 \\
\hline $\mathbf{S}_{2}$ & 41.28 & 43.92 & 42.59 & 18.71 & 20.00 & 19.35 & 40.25 & 43.70 & 41.97 \\
\hline $\mathbf{S}_{3}$ & 39.60 & 42.53 & 41.05 & 16.93 & 18.22 & 17.57 & 37.18 & 40.82 & 38.98 \\
\hline $\mathbf{S}_{4}$ & 38.35 & 38.92 & 38.63 & 15.68 & 16.29 & 15.98 & 35.01 & 37.12 & 36.07 \\
\hline $\mathbf{S}_{5}$ & 24.24 & 26.45 & 25.33 & 9.23 & 9.91 & 9.57 & 21.87 & 25.13 & 23.48 \\
\hline \multirow[t]{2}{*}{ Mean } & 37.27 & 40.11 & & 16.19 & 17.15 & & 35.16 & 38.38 & \\
\hline & \multicolumn{2}{|l|}{ S.Em \pm} & C.D at $5 \%$ & S.Em \pm & \multicolumn{2}{|c|}{ C.D at $5 \%$} & S.Em \pm & \multicolumn{2}{|c|}{ C.D at $5 \%$} \\
\hline Main plot (M) & \multicolumn{2}{|l|}{0.67} & 2.01 & 0.28 & & .82 & 1.10 & & 3.30 \\
\hline Subplot (S) & 1.20 & & 3.54 & 0.87 & & .50 & 1.01 & & 3.00 \\
\hline M at same level of $\mathbf{S}$ & 1.65 & & 4.78 & 0.29 & & .84 & 1.15 & & 3.42 \\
\hline $\begin{array}{l}\text { S at same or different } \\
\text { level of } M\end{array}$ & 1.70 & & 4.81 & 0.30 & & .88 & 1.09 & & 3.27 \\
\hline Main plot treatments: Till & practices $(\mathbb{M}$ & & Sub plot treat & Nutrient $m$ & agement & tices (S) & & & \\
\hline $\mathrm{M}_{1}:$ Reduced tillage & & & $\mathbf{S}_{\mathbf{1}}:$ Recommen & ose of fertiliz & + FYM(6 & $: 75 \mathrm{~N}: \mathrm{P}_{2} \mathrm{O}$ & +FYM @ 2: & $\left.a^{-1}\right)$ & \\
\hline $\mathrm{M}_{2}$ : Conventional tillage & & & $\mathbf{S}_{2}:$ Recommen & ose of inorgar & fertilizer & $00: 75 \mathrm{~N}: \mathrm{P}$ & $\left.\mathrm{O} \mathrm{kg} \mathrm{ha}^{-1}\right)$ & & \\
\hline DAS : Days after sowing & & & $\mathbf{S}_{3}$ : Integrated 1 & nt managemer & $50 \% \operatorname{Rec}$ & rough ino & fertilizer +5 & Rec. $\mathrm{N}$ th & h FYM) \\
\hline NS : Non significant & & & $\mathbf{S}_{\mathbf{4}}$ : Organic nu & management & $5 \%$ Rec. 1 & ugh FYM & Rec. $\mathrm{N}$ thro & poultry 1 & \\
\hline
\end{tabular}


Table.2 Available nitrogen, phosphorous and potassium $\left(\mathrm{kg} \mathrm{ha}^{-1}\right)$ content in soil after the harvest of Pole bean as influenced by tillage and nutrient management practices

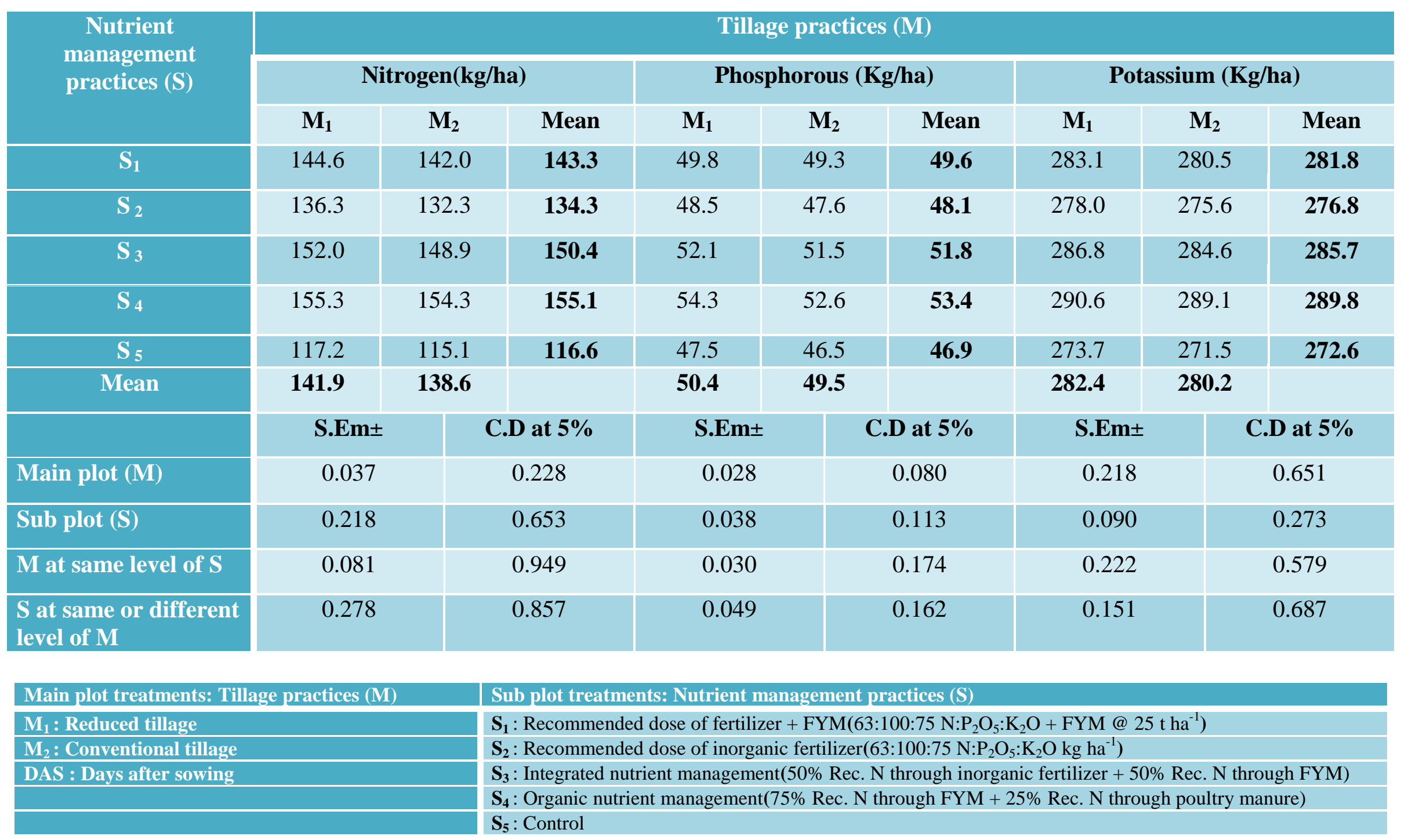


Table.3 Enumeration of microflora (Bacteria, fungi and actinomycetes) of Polebean as influenced by tillage and Nutrient management practices

\begin{tabular}{|c|c|c|c|c|c|c|c|c|c|}
\hline \multirow{3}{*}{$\begin{array}{c}\text { Nutrient } \\
\text { management } \\
\text { practices (S) }\end{array}$} & \multicolumn{9}{|c|}{ Tillage practices (M) } \\
\hline & \multicolumn{3}{|c|}{$\begin{array}{c}\text { Bacteria } \\
\left(\text { CFU } \times 10^{-6} \mathrm{~g}^{-1} \text { soil }\right)\end{array}$} & \multicolumn{3}{|c|}{$\begin{array}{c}\text { Fungi } \\
\left(\text { CFU X 10 } \text { 10 }^{-4} \mathrm{~g}^{-1} \text { soil }\right)\end{array}$} & \multicolumn{3}{|c|}{$\begin{array}{c}\text { Actinomycetes } \\
\text { (CFU X 10 } 0^{-3} \mathrm{~g}^{-1} \text { soil) }\end{array}$} \\
\hline & \multicolumn{2}{|c|}{$\begin{array}{ll}M_{1} & M_{2}\end{array}$} & Mean & $\mathbf{M}_{1}$ & $\mathbf{M}_{2}$ & Mean & $\mathbf{M}_{1}$ & $\mathbf{M}_{2}$ & Mean \\
\hline $\mathbf{S}_{1}$ & 82.3 & 83.0 & 82.7 & 28.0 & 28.7 & 28.3 & 46.0 & 49.0 & 47.5 \\
\hline$\overline{\mathbf{S}_{2}}$ & 60.7 & 74.0 & 67.3 & 19.7 & 26.0 & 22.8 & 36.0 & 42.0 & 39.0 \\
\hline $\mathbf{S}_{3}$ & 59.0 & 62.0 & 60.5 & 19.0 & 24.3 & 21.7 & 33.0 & 41.3 & 37.2 \\
\hline $\mathbf{S}_{4}$ & 52.7 & 58.7 & 55.7 & 14.0 & 18.3 & 16.2 & 28.7 & 29.0 & 28.8 \\
\hline $\mathbf{S}_{5}$ & 47.0 & 49.7 & 48.3 & 12.0 & 13.7 & 12.8 & 24.0 & 26.0 & 25.0 \\
\hline \multirow[t]{2}{*}{ Mean } & 60.3 & 65.5 & & 18.9 & \multicolumn{2}{|l|}{21.9} & 33.5 & 37.5 & \\
\hline & S.Em \pm & \multicolumn{2}{|r|}{ C.D at $5 \%$} & S.Em \pm & \multicolumn{2}{|c|}{ C.D at $5 \%$} & \multicolumn{2}{|l|}{ S.Em \pm} & C.D at $5 \%$ \\
\hline Main plot (M) & \multicolumn{2}{|l|}{0.253} & 0.759 & 0.416 & \multicolumn{2}{|r|}{1.314} & \multicolumn{2}{|l|}{0.740} & 2.227 \\
\hline Sub plot (S) & \multicolumn{2}{|l|}{0.554} & 1.661 & 0.247 & & 0.741 & 0.363 & & 1.089 \\
\hline M at same level of $\mathbf{S}$ & 0.279 & & 2.454 & 0.483 & & 0.174 & 0.760 & & 2.194 \\
\hline $\begin{array}{l}\text { S at same or different } \\
\text { level of } M\end{array}$ & 0.712 & & 2.229 & 0.380 & & 0.162 & 0.572 & & 2.441 \\
\hline Main plot treatments: Til & practices $(\mathrm{M}$ & & Sub plot trea & Nutrient n & agement & practices (S) & & & \\
\hline $\mathrm{M}_{1}$ : Reduced tillage & & & $\mathbf{S}_{1}:$ Recomme & se of fertiliz & FYM(6 & $: 100: 75 \mathrm{~N}: \mathrm{P}_{2} \mathrm{C}$ & +FYM@2. & $\left.\mathrm{ha}^{-1}\right)$ & \\
\hline $\mathbf{M}_{2}$ : Conventional tillage & & & $\mathbf{S}_{2}$ : Recomme & se of inorga & fertilizer & 63:100:75 N:P & $\left.\mathrm{O} \mathrm{kg} \mathrm{ha}{ }^{-1}\right)$ & & \\
\hline DAS : Days after sowing & & & $\mathbf{S}_{3}$ : Integrated & t manageme & $5 \% \operatorname{Rec}$ & $\mathrm{N}$ through ino & ertilizer +50 & $\operatorname{Rec} . \mathrm{N}$ & hrough FYM) \\
\hline & & & $\mathbf{S}_{4}$ : Organic $\mathrm{n}$ & nanagement & $\%$ Rec. I & through FYM & Rec. $\mathrm{N}$ throu & poultry & manure) \\
\hline
\end{tabular}




\section{Microbial population}

Among the tillage practices, conventional tillage recorded significantly higher number of soil bacterial $\left(65.5 \mathrm{CFU} \times 10^{-6} \mathrm{~g}^{-1}\right.$ soil),fungi (21.5 CFU x $10^{-4} \mathrm{~g}^{-1}$ soil) and actinomycetes (37.5 CFU x $10^{-3} \mathrm{~g}^{-1}$ soil) population over reduced tillage $(60.3 \mathrm{CFU} \times$ $10^{-6} \mathrm{~g}^{-1}$ soil, $18.9 \mathrm{CFU} \times 10^{-4} \mathrm{~g}^{-1}$ soil and $33.5 \mathrm{CFU} \times 10^{-3} \mathrm{~g}^{-1}$ soil, respectively).

Among nutrient management practices, application of recommended dose of fertilizer and FYM recorded significantly higher number of soil bacterial $\left(82.7 \mathrm{CFU} \times 10^{-6} \mathrm{~g}^{-1}\right.$ soil), fungi (28.3 CFU $\times 10^{-4} \mathrm{~g}^{-1}$ soil) and actinomycetes (47.5 CFU x $10^{-3} \mathrm{~g}^{-1}$ soil) over all other treatments. Unfertilized control recorded significantly lower number of soil bacterial (48.3 CFU $\times 10^{-6} \mathrm{~g}^{-1}$ soil), fungi (12.8 CFU x $10^{-4} \mathrm{~g}^{-1}$ soil) and actinomycetes (25.0 CFU x $10^{-3} \mathrm{~g}^{-1}$ soil). Interaction of main and sub plot treatments, significantly higher number of soil bacterial $\left(83.0 \mathrm{CFU} \times 10^{-6} \mathrm{~g}^{-1}\right.$ soil), fungi (28.7 CFU x $10^{-4} \mathrm{~g}^{-1}$ soil) and actinomycetes (49.0 CFU x $10^{-3} \mathrm{~g}^{-1}$ soil) were observed in conventional tillage with recommended dose of fertilizer and FYM compared to all other treatments. Reduced tillage (Table 3) with unfertilized control recorded significantly lower number of soil bacterial (47.0 CFU $\times 10^{-6} \mathrm{~g}^{-1}$ soil), fungi (12.0 CFU x $10^{-4} \mathrm{~g}^{-1}$ soil) and actinomycetes (24.0 CFU $\times 10^{-3} \mathrm{~g}^{-1}$ soil) followed by conventional tillage with unfertilized control (49.7, 13.7 and 26.0, respectively). These results are in line with the findings of Sharada (2013) who reported higher soil microbial population with combined application of organics and inorganics.

The results of the investigation revealed that significantly higher uptake of nutrients by pole bean, available nitrogen, phosphorus and potassium in soil and higher number of soil bacterial, soil fungi and soil actinomycetes population were recorded with reduced tillage and conventional tillage.

\section{References}

AbdulkadirIman Sh. Mohamoud, 2000, Effect of poultry waste composts and fertilizer levels on the growth and productivity of maize (Zea may L.). M.Sc Agri. Thesis, Univ. of Agric. Sci., Bangalore.

Cabeda, 1984, Effect of tillage on soil physical properties. E. Giasson Soil Dept. The Federal Univ. of Riograde Do Shl.PortoAlgere, Brazil.

Dhawan, A. S.; Singh, K. D. and Goswami, N. N. 1992.Suitability of soil test methods for rice and wheat under field conditions. J. Indian Soc. Soil Sc. 40: 216-217.

Jackson, M. L., 1973, Soil Chemical Analysis. Prentice hall of India (Pvt.), New Delhi, pp. 67-214.

Jagdale, R.B., Khawale, V. S., Baviskar, P. K., Doshinge, B.B. and Kore, M.S., 2005, Effect of inorganic and organic nutrients on growth and yield of French bean (Phaseolus vulgaris L.). J. Soil and Crops, 15: 401-405.

Jakhar, P., Singh, J. and Nanwal, R.K., 2005, Nutrient content and uptake in wheat (Triticum aestivum L.) as influenced by tillage methods, biofertilizers and nitrogen levels. Harayana J. Agron., 21 (1): 75-77.

Katkar, R.N., Turkhede, A.B., Solanke, V.M., Wankhade, S.T. and Patil, M.R., 2002, Effect of integrated management of organic manures and fertilizers on soil properties and yield of cotton. $J$ Cotton Res. Dev., 16(1):89-92.

Muthuramalingam, S., Sendurkumaran, S., Muthuvel, I. and Sathyamurhty, V.A., 2002, Influence of plant densities and applied nutrients on uptake of NPK in seed propagated aggegatum onion. Crop Res., 23(3): 481-485. 
Panse, V. G. and Sukhatme, P. U., 1967, Statistical Methods for Agricultural Workers. ICAR, New Delhi.

Pramer, D. and Schmidt, E. L., 1964, Experimental soil microbiology. Burgers Pub. Minneapolis, Minnesota, USA.

Prasad, F.M., Chandra, A. and Singh, K., 1998, Effect of phosphorus and organic matter on dry matter, yield and nutrient uptake in wheat. The Allahabad Farmer, 111: 117-122.

Prasad, R., 1994, Evaluation of methods for available $\mathrm{N}, \mathrm{P}$ and $\mathrm{K}$ for rice and maize under field condition in inceptisol. $J$. Indian Soc. Soil Sci., 42 (2): 318-320.

Rajput, Pankaj Kumar, Singh, O.N., Singh, Yogeshwar and Singh, J.P., 2006, Integrated nutrient management for quantitative and qualitative yield of French bean (Phaseolus vulgaris L.). Veg. Sci., 33 (2): 155-159.

Reddy, G.B. and Reddy, S.M., 1998, Effect of organic manures and nitrogen levels on soil available nutrient status in maize soybean cropping system. J. Indian Soc. Soil Sci., 46(3): 474-476.

Samra, J.S. and Dhillon, S.S., 2000, Production potential of rice (Oryza sativa) - wheat (Triticum aestivum) cropping system under different methods of crop establishment. Indian J. Agron., 45 (1): 21-24.

Shamra, J.P. and Saxena, S.N., 1985, Utilization of phosphorus by maize as influenced by various sources of organic matter and applied phosphorus. J. Indian Sco. Soil Sci., 33: 561-567.

Sharada, 2013, Studies on nutrient management practices through organics in greengram - Rabi sorghum cropping system. M.Sc. (Agri.) Thesis, Univ. Agric. Sci., Raichur.

Veeresh, N.K., 2003, Response of French bean (Phaseolus vulgaris L.) to fertilizer levels in Northern Transitional Zone of Karnataka. M.Sc. (Agri.) Thesis, Univ. Agric. Sci., Dharwad. p. 37-79.

\section{How to cite this article:}

Nilesh Shiragavi, D. Krishnamurthy, Y.M. Ramesha, H.S. Latha and Nrayanarao, K. 2018. Effect of Tillage and Nutrient Management Practices to Pole Bean (Phaseolus vulgaris L.) on Nutrient Uptake, Soil Fertility Status and Microbial Population. Int.J.Curr.Microbiol.App.Sci. 7(09): 2140-2147. doi: https://doi.org/10.20546/ijcmas.2018.709.262 